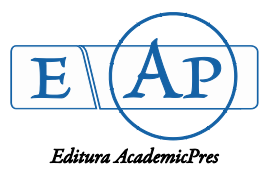

\title{
Timing of Reproductive Organs Maturity in Proterandrous Malva sylvestris $\mathrm{L}$.
}

\author{
Aslihan ÇETİNBAŞ-GENÇ*, Meral ÜNAL \\ Marmara University, Department of Biology, Göztepe Campus, 34730 Istanbul, \\ Turkey; aslihan.cetinbas@marmara.edu.tr (*correspondingauthor);meralunal@marmara.edu.tr
}

\begin{abstract}
Flower development of protandrous species Malva sylvestris L. was divided into 12 stages, as revealed by applying histological and scanning electron microscope techniques. Flower development started with the conversion of apical meristem into floral meristem. Initiation of male organ primordia started before that of female organ. Five rounded structures called corolla/androecium units differentiated from floral meristem, on which stamen primordia emerged. When pollen mother cells exist in the pollen sacs, initiation of carpels starts from floral meristem. Concurrent with the termination of meiosis in pollen mother cells, ten loculed ovary comed in view. Simultaneously with the occurrence of vacuoleted pollen grains, megaspore mother cell becomes visible in the nucellar tissue. Concominant with the existence of two celled-pollen grains, the style was formed and ovule becomes anatropous. When pollen grains are shed in male phase, ten branched stigma appeared on the upper part of the style, but receptive surface was not fully formed to accept pollen grains. Female phase is characterized by the opening of stigmatic branches with papillate receptive surface. Timing of reproductive organs maturity overlapped for a while, thus, the reproductive stragey of $M$. sylvestris was incomplete proterandry.
\end{abstract}

Keywords: dichogamy, floral organogenesis, incomplete dichogamy, protandrous, reproductive biology

\section{Introduction}

Malva sylvestris L. (common mallow) is a member of Malvaceae (Razavi et al., 2011), with approximately 243 genera and more than 4,225 species (Stevens, 2001). Common mallow is an annual plant (Hussain et al., 2014) with shallowly lobed leaves (Razavi et al., 2011) and purple flowers (Kumar et al., 2014). The plant prefers damp areas, such as the ocean, salt marshes, meadows, sides of ditches and banks of tidal rivers (Davis, 1966).

M. sylvestris has medicinal importance and its flowers and leaves are used as a treatment of cut wound, eczema, dermal infected wounds, bronchitis, digestive problems, inflammations (Pirbalouti et al., 2009), liver diseases, cold, cough (Farina et al., 1995), burn (Pirbalouti et al., 2009; Ghorbani, 2005) and haemorrhoids (Nawwar, 1991). Besides, they are also used as vegetable and tea (Razavi et al., 2011).

Hermaphrodite flowers of M. sylvestris (Kumar et al., 2014) consist of tubular group of stamens surrounding the pistil. Anthers are kidney-shaped. Pistil has united style ending in the free stigmas, which are equal in number to the carpels. Ovary is superior, with numerous loculi. Each loculus contains a single ovule showing axillar placentation (Hickey and Clive, 1997).
Flower ontogeny and reproductive biology in angiosperms is one of the significant issues, for providing useful data in the fields of taxonomy, seed production and outbreeding mechanisms. Emerging of the development stages of floral organs is an important division of plant developmental biology, being one of the main basic topics (Kinney et al., 2008). Development in a hermaphrodite flowers starts with the differentiation of apical meristem. Afterwards, apical meristem transforms into the floral meristem (Bernier et al., 1993). All the members of Malvaceae share a uniform pattern of floral development (Balthazar et al., 2004) and sepal, petal, stamen and carpel differentiate from floral meristem respectively (Atsmon and Galun, 1960).

Dichogamy is the maturation of sex organs at different times and can be interpreted as a floral mechanism favouring cross-pollination. It commonly exists among angiosperms and it has two main subtypes; proterandry and proterogyny (Routley et al., 2004; Çetinbaş and Ünal, 2014). In proterandry, stamen gains reproductive maturity much before the stigma attains receptivity in a hermaphrodite flower. In proterogyny, pistil gains reproductive activity much before the anther dehisces (Morbey and Ydenberg, 2001). Also, dichogamy has two subtypes according to the degree of stamen and pistil

Received: 14 May 2017. Received in revised form: 01 Jun 2017. Accepted: 05 Jun 2017. Published online: 30 Jun 2017. 
288

separation; complete and incomplete. In complete dichogamy, the reproductive maturity of the stamen and pistil does not occur at the same time. In some cases reproductive activity of the male and female sex organs temporally overlaps during a certain period of time and it is termed as incomplete dichogamy (Lloyd and Webb, 1986). M. sylvestris exhibits protandrous dichogamy, as previously described by Kumar et al. (2014) focused on phenological characteristics of this species.

Despite extensive medical, pharmacological, phytochemical and chemical studies in $M$. sylvestris, there is no comparative histological study about timing of sexual organ development. A detailed ontogenic and reproductive description of the species would therefore, provide a significant knowledge for future studies that would ultimately give a better understanding of the mechanism of proterandrous dichogamy. To this end, we followed the course of developmental events through the period of sex organ initiation and maturity, dividing into 12 stages by the application of cytological and scanning electron microscope (SEM) techniques.

\section{Materials and Methods}

The flowers of M. sylvestris at various stages of development were collected from Belgrad Forest (İstanbul / Turkey). Firstly, the diameter of the flowers were measured and morphologically analysed by Olympus 970931 stereomicroscope. The samples were prepared for light, fluorescence and SEM analysis.

The material was fixed in acetic-alcohol $(1: 3, \mathrm{v} / \mathrm{v})$ and then placed in a vacuum desiccator to facilitate the penetration of the fixative into the plant tissues. After embedding in paraffin, the blocks were sectioned at 5-12 $\mu \mathrm{m}$ by Leica RM-2235 rotation microtome. For histological studies, the sections were stained with Delafield's hematoksilin and Auramine O (Heslop-Harrison and Shivanna, 1977). The preparations were photographed with an Evolution LC color camera and an Olympus BH-2 microscope, and the images were analyzed with Image-Pro Express Version 6.0 scientific image processing and analysis software. The Auramine $\mathrm{O}$ preparations were investigated with Leica DM LB2 fluorescence microscope at respectively $440 \mathrm{~nm}$ and $365 \mathrm{~nm}$ wavelength and photographed with Leica DFC 329 fluorescence camera.

For SEM analysis, the plant material was fixed in $2.5 \%$ glutaraldehyde in $50 \mathrm{mM}$ cacodylate buffer, $\mathrm{pH} 7.0$ (Platt et al., 1983) and then dehydrated with an increasing ethanol gradient: from $70 \%$ up to $100 \%$. Then, the material for drying were kept in ethanol-hexamethyldisilazane solutions at room temperature (Topçuoğlu et al., 2009). Then, coated with $11 \mathrm{~nm}$ of gold by using an automated sputter coater and then examined with JEOL JMS-59 10LV SEM.

\section{Results}

\section{Flower morphology}

M. sylvestris bears hermaphrodite flowers with five purple petals. Mature flowers include a tubular structure formed by numerous stamens, an ovary with ten loculi, a thick style and ten branched, papillose stigma. The male phase is followed by the female phase and the male phase is characterized by the anther maturation and pollen shedding (Fig. 1 A). At the end of the first phase, the style lengthens until it is exerted from the anther tube. Concurrent with full extension, the stigmatic branches open and the receptive surface become papillate. Thus, the flowers enter the female phase and the stigma attains receptivity (Fig. 1 B).

We divided the developmental events starting from apical meristem initiation to maturity of reproductive organs into 12 stages, based on stereo, light and scanning electron microscopes observations.

\section{Stage 1: Flower initiation}

Flower initiation starts with the differentiation of apical meristem as a rounded bulge (Fig. 2). The apical meristem expands, flattens and transforms into the floral meristem that will generate floral organ primordia (Fig. 2 B). The cells of apical and floral meristem have dense cytoplasm, big nucleus and small vacuoles.

\section{Stage 2: Corolla / androecium units initiation}

Five rounded structures, that will form stamen and corolla primordia, initiate as a protrusion from the sides of floral meristem (Fig. 2 C). These structures, called corolla / androecium units (CAU), grow and elongate in the course of development.

\section{Stage 3: Stamen primordia initiation}

Stamen primordia differentiate as circular bulge on CAU (Fig. 3 A). During development, CAU continue their extension with the stamen primordia on them (Fig. $3 \mathrm{~B}$ ).

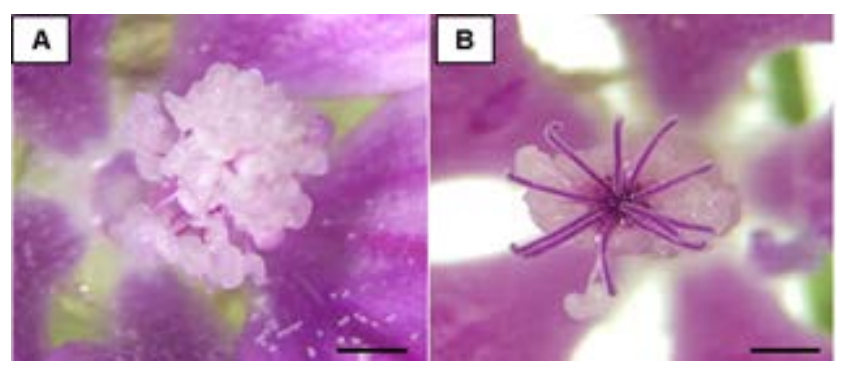

Fig. 1. Flower morphology and reproductive phases in $M$. sylvestris, as seen in stereomicroscope A. Male phase: The mature stamens. Note the pollen grains on petals. B. Female phase: Ten open branched mature stigma with papillate receptive surface. Bar: $1 \mathrm{~mm}(\mathrm{~A}, \mathrm{~B})$

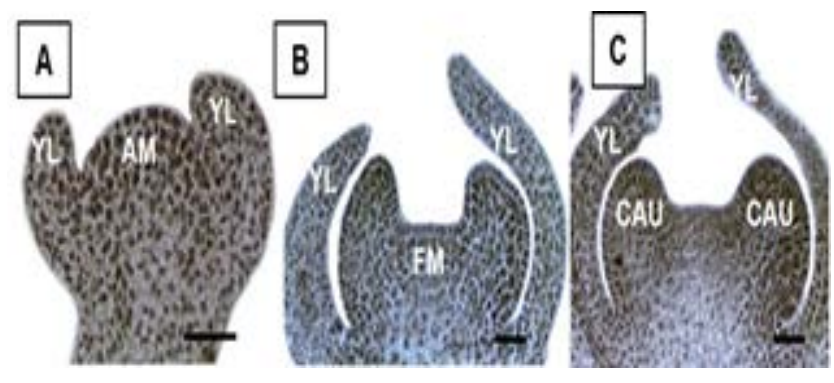

Fig. 2. Stage 1: Flower initiation (A, B) and Stage 2: CAU initiation (C) in M. sylvestris. A. Apical meristem. B. Floral meristem. C. Initiation of CAU. AM: Apical meristem, CAU: Corolla / androecium units, FM: Floral meristem, YL: Young leaf. Bar: $5 \mu \mathrm{m}(\mathrm{A}-\mathrm{C})$ 
Stage 4: Stamen differentiation into anther and filament

In the course of stamen development, firstly filaments as a conical projections and then anthers differentiate (Fig. 3 C). The young anthers consist of homogeneous masses of cells surrounded by epidermis (Fig. 3 D). Archesporial cells, which have prominent nuclei and dense cytoplasm, become visible in each sporangium (Fig. 3 E). They undergo divisions to form parietal and sporogenous tissues.

In stage 4, concomitant with the appearance of slightly lobed anther (Fig. 3 F), CAU continue to elongation (Fig. $3 \mathrm{C}$ ).

Stage 5: Anther wall layers and sporogenous tissue

Anther wall layers, epidermis, endothecium, middle layer and tapetum, are formed by successive divisions of the parietal layer (Fig. $4 \mathrm{~A}$ ).

In stage 5, anthers become tetrasporangiate (Fig. $4 \mathrm{~B}$ ) and sporogenous tissues are apparent (Fig. 4 A, B). Elongation of CAU continues. Nevertheless, carpel primordia have not differantiated from floral meristem yet.

\section{Stage 6: Corolla initiation}

Concurrent with tetrasporangiate anthers, corolla primordia differentiate as sharp bulges from the base of CAU (Fig. 4 C, D).

In stage 6, CAU maintain their elongation and start to form a tubular structure (Fig. 4 C).

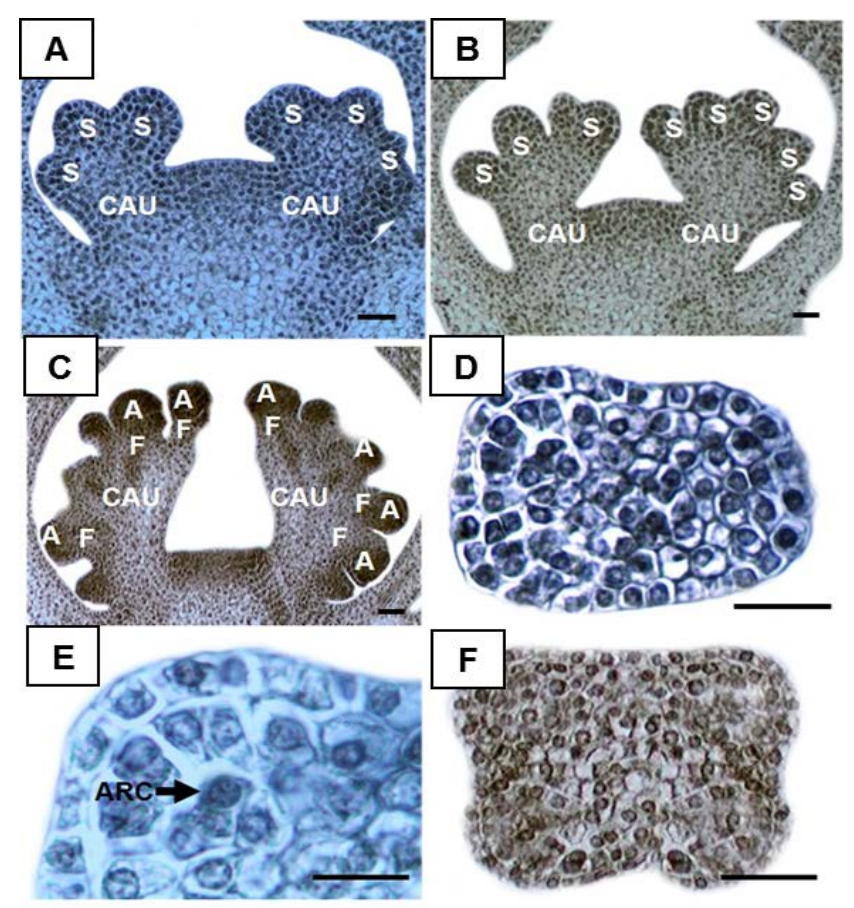

Fig. 3. Stage 3: Stamen primordia initiation (A, B) and Stage 4: Stamen differantiation into anther and filament (C, D, E, F). A. Stamen primordia differentiation on CAU. B. CAU elongation with stamen primordia. C. Anther-filament differentiation and CAU elongation. D. Transverse section of a young anther. E. Archesporial cell (arrow). F. Slightly lobed anther. A: Anther, ARC: Archesporial cell, CAU: Corolla/androecium units, F: Filament, S: Stamen primordia. Bar: $2 \mu \mathrm{m}(\mathrm{E}), 5 \mu \mathrm{m}(\mathrm{A}, \mathrm{B}, \mathrm{C}, \mathrm{D}, \mathrm{F})$
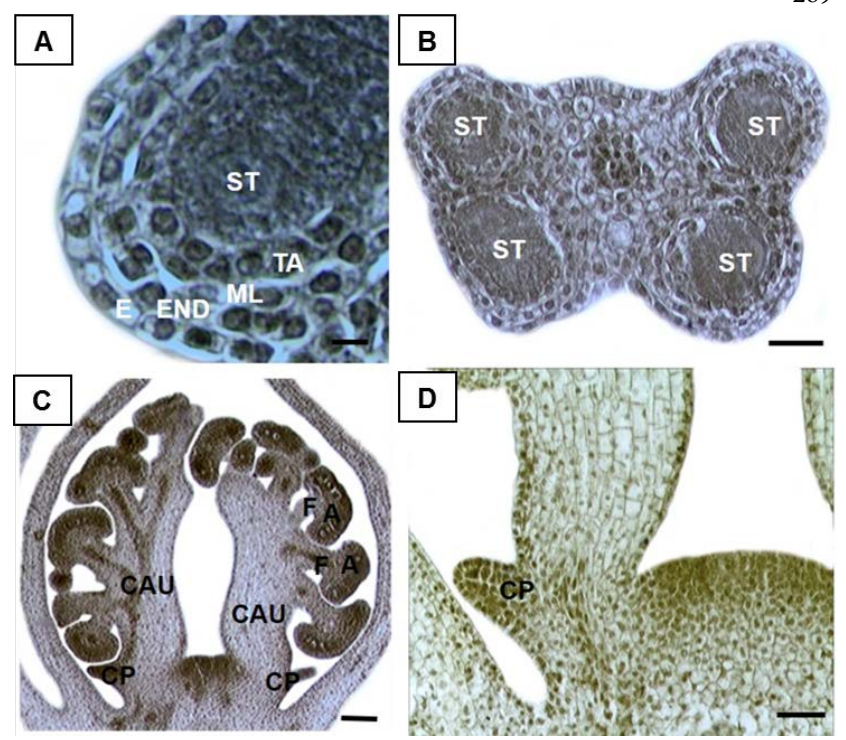

Fig. 4. Stage 5: Anther wall layers and sporogenous tissue formation (A, B) and Stage 6: Corolla initiation (C, D). A. Proper anther wall layers and sporogenous tissue. $B$. Tetrasporangiate anther. C. Tubular structure formed by CAU. D. Corolla initiation. A: Anther, CAU: Corolla/androecium units, CP: Corolla primordium, E: Epidermis, END: Endothecium, F: Filament, ML: Middle layer, ST: Sporogen tissue, TA: Tapetum. Bar: $1 \mu \mathrm{m}(\mathrm{A}), 5 \mu \mathrm{m}$ (B), $10 \mu \mathrm{m}(\mathrm{C}, \mathrm{D})$.

\section{Stage 7: Carpel primordia initiation}

After the occurrence of corolla primordia, ten carpel primordia differentiate from floral meristem (Fig. 5 A).

In stage 7, pollen mother cells (PMCs) exist in pollen sacs (Fig. 5 B). It is noteworthy the existence of a small number and large volume of the PMCs. Each pollen sac contains 1-4 PMCs. The epidermis and endothecium keep developing, the middle layer gets thin and the tapetum elongates longitudinally (Fig. 5 B).

\section{Stage 8: Ovary and ovule formation}

The carpel primordia grow longer and approach each other (Fig. 5 C) and 10 loculed ovary comes in view (Fig. 5 D, F, G). Shortly after the ovary formation, ovules start to differentiate as small projections on the placenta in ovarian cavity by axile placentation. Freshly differentiated cells have dense cytoplasms and small nuclei (Fig. 5 E).

In stage 8 , microspore tetrads are formed at the termination of meiosis in the pollen sacs (Fig. $5 \mathrm{H}$ ). In another wall, the epidermis thins and the middle layer disappears completely. Wall thickenings arise in the endothecium and the tapetum reaches its maximum size (Fig. $5 \mathrm{H}$ ). The corolla primordia extend and start to get taper (Fig. 5 I). The CAU form a tube surrounding the carpel primordia (Fig. $5 \mathrm{~J}$ ).

\section{Stage 9: Megasporemother cell differentiation}

Megaspore mother cell differantiates below a few cells of the nucellar epidermis, which is conspicuous by its large size, bigger nucleus and denser cytoplasm (Fig. $6 \mathrm{~A}$ ).

In stage 9, simultaneously with start of ovule curvature, integument primordia differentiate from the nuclear base independently. The inner integument appears before the 


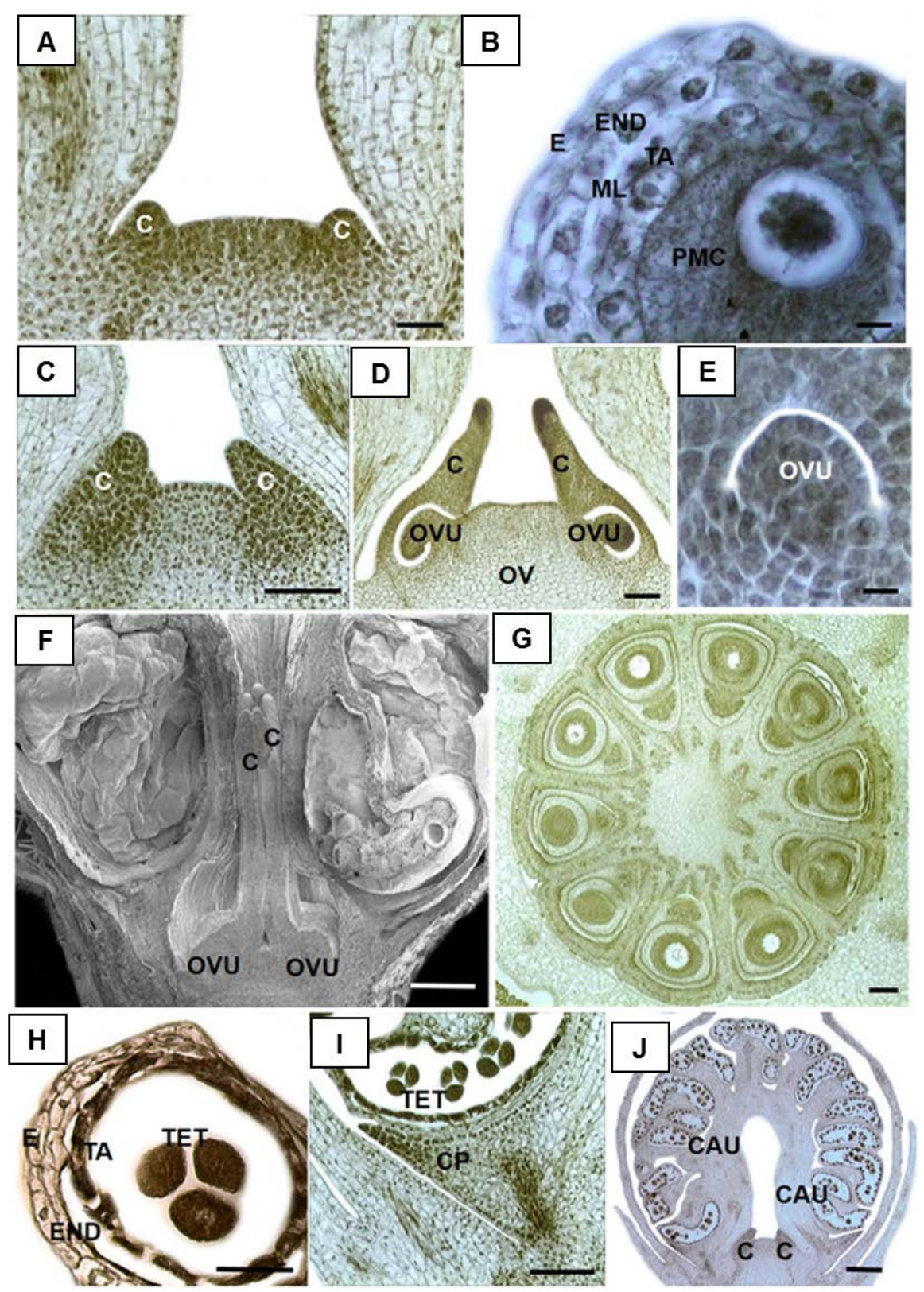

Fig. 5. Stage 7: Carpel primordia initiation (A, B) and Stage 8: Ovary and ovule formation (C-J). A. Carpel primordia differentiation. B. PMC with generous cytoplasm and huge nucleus. C. Growing upwardly of carpel primordium. D. Ovary and ovule formation. E. Ovule initiation. F. Growing and approaching to each other of carpel primordia, as seen in SEM (Five of ten). G. An ovary with 10 loculi. H. Anther wall layers and microspore tetrad. I. Corolla primordia elongation. J. CAU units elongation. C: Carpel primordia, CAU: Corolla/androecium units, CP: Corolla primordium, E: Epidermis, END: Endothecium, ML: Middle layer, OV: Ovary, OVU: Ovule, PMC: Pollen mother cell, TA: Tapetum, TA: Tapetum, TET: Tetrad. Bar: $1 \mu \mathrm{m}(\mathrm{B}, \mathrm{E}), 5 \mu \mathrm{m}(\mathrm{H}, \mathrm{I}), 10 \mu \mathrm{m}(\mathrm{A}, \mathrm{C}, \mathrm{D}, \mathrm{G}), 20 \mu \mathrm{m}(\mathrm{J}), 200 \mu \mathrm{m}(\mathrm{F})$

outer integument (Fig. 6 B). Vacuolated pollen grains are present in the anthers (Fig. $6 \mathrm{C}$ ). The carpel primordia keep their elongation.

\section{Stage 10: Styleformation}

Along the development, the carpel primordia merge on the ovary and they form a single, thick style (Fig. 7 A, B, C) located in the tube formed by CAU (Fig. 7 B).

In stage 10 , curvature of ovule continues and ovule becomes anatropous (Fig. 7 D). Megaspore mother cell undergoes meiosis to give rise a dyad (Fig. 7 E) and a linear megaspore tetrad (Fig. 7 F). Mature pollen grains are located in the anthers (Fig. $7 \mathrm{G}$ ). While the tapetum and the middle layer are completely disappeared, the epidermis and the endothecium remain as anther wall layers (Fig. $7 \mathrm{G}$ ). The corolla is mature, very sharp and thin (Fig. $7 \mathrm{H}, \mathrm{I})$.

\section{Stage 11: Stigma formation}

Ten branched stigma differentiates on the upper part of the style (Fig. $8 \mathrm{~A}$ ). Newly formed stigma is not covered by 

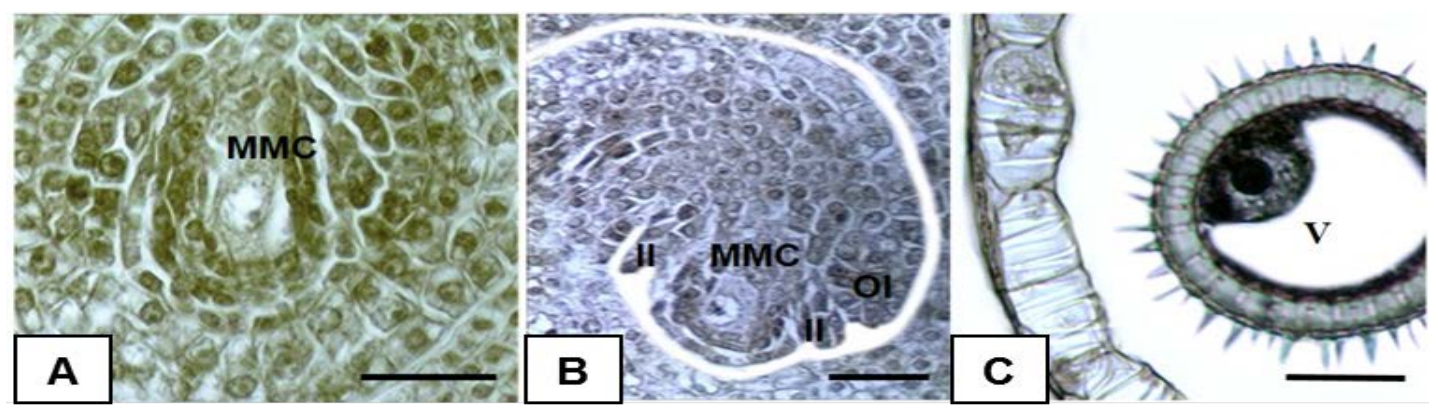

Fig. 6. Stage 9: Megaspore mother cell differentiation. A. Megaspore mother cell. B. Integuments initiation. C. Vacuolated pollen grain. II: Inner integument, MMC: Megaspore mother cell, OI: Outher integument, V: Vacuole. Bar: $5 \mu \mathrm{m}$ (A-C)
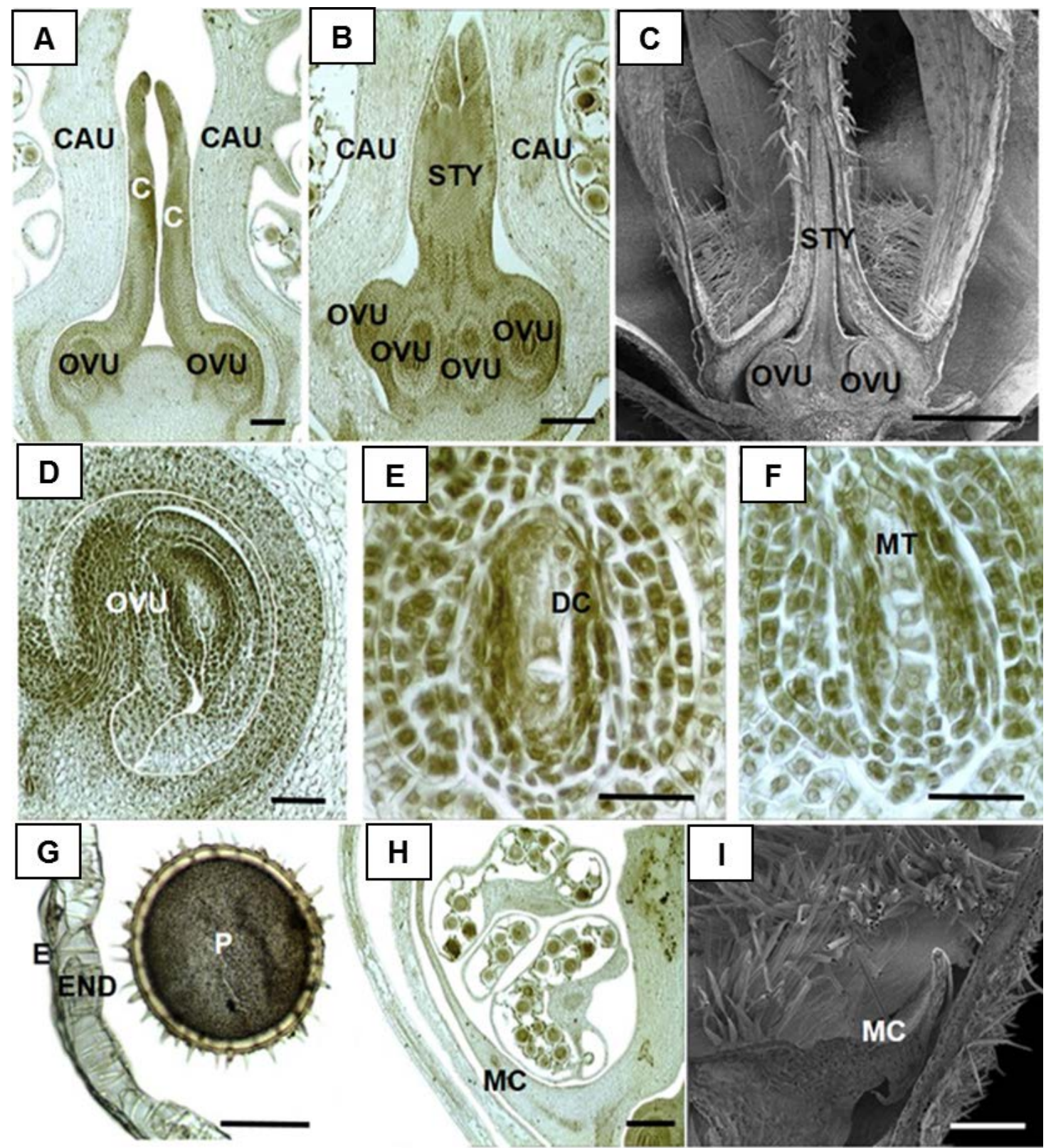

Fig. 7. Stage 10: Style formation. A. Growing and approaching to each other of carpel primordia. B. Single and thick style formation. C. SEM analysis of single and thick style. D. Anatropous ovule. E. Dyad cells. F. Linear megaspore tetrad. G. Very thin epidermis, wall tickenings in the endothecium and a mature pollen. H. Mature corolla in bowl appearance. I. SEM analysis of thin, sharp mature corolla. C: Carpel primordium, CAU: Corolla/androecium units, DC: Diad cells, E: Epidermis, END: Endothecium, MC: Mature corolla, MT: Megaspor tetrad, OVU: Ovule, P: Pollen, STY: Style. Bar: $5 \mu \mathrm{m}$ (G, E, F), $10 \mu \mathrm{m}(\mathrm{A}$, D), $20 \mu \mathrm{m}(\mathrm{B}, \mathrm{H}), 200 \mu \mathrm{m}(\mathrm{I}), 1 \mathrm{~mm}(\mathrm{C})$ 
292

papillae and stigmatic branches are not separated. Stigma is not ready to accept the pollen grains (Fig. $8 \mathrm{~B}$ ).

In stage 11 , mitotic divisions in the functional megaspore result in the formation of 2, 4 and 8 nucleated embryo sac (Fig. 8 C, D). Mature, eight nuclated embryo sac contains an egg cell, two synergids, two polar nuclei and three antipodal cells (Fig. $8 \mathrm{E}, \mathrm{F}, \mathrm{G}, \mathrm{H}$ ). In this stage, when the stigma does not gain reproductive maturity, pollen grains are shed from the anthers by stomium (Fig. 8I). As revealed by SEM analysis, pollen grains of $M$. sylvestris are periporatae, sphaeroidea and the average diameter of a mature pollen is $100-120 \mu \mathrm{m}$. The exine of mature pollen grain has thin, short and spike like projections (Fig. $8 \mathrm{~J}$ ).

\section{Stage 12: Stigma receptivity}

When stigma attains maturity, the stigmatic branches open and their receptive surface become covered with unicellular and uniseriate papilla. The average length of a papilla is $100-150 \mu \mathrm{m}$. In this case, the stigma is ready to accept the pollen grains.

In stage 12 , pollen shedding continues for a short time, and then the stamens become blunt. So, timing of the stamen and pistil maturity is overlap for a while (incomplete dichogamy). In this manner, the pollen grains can be observed on the stigma branches and self-fertilization may also occur (Fig. 9 A, B, C).
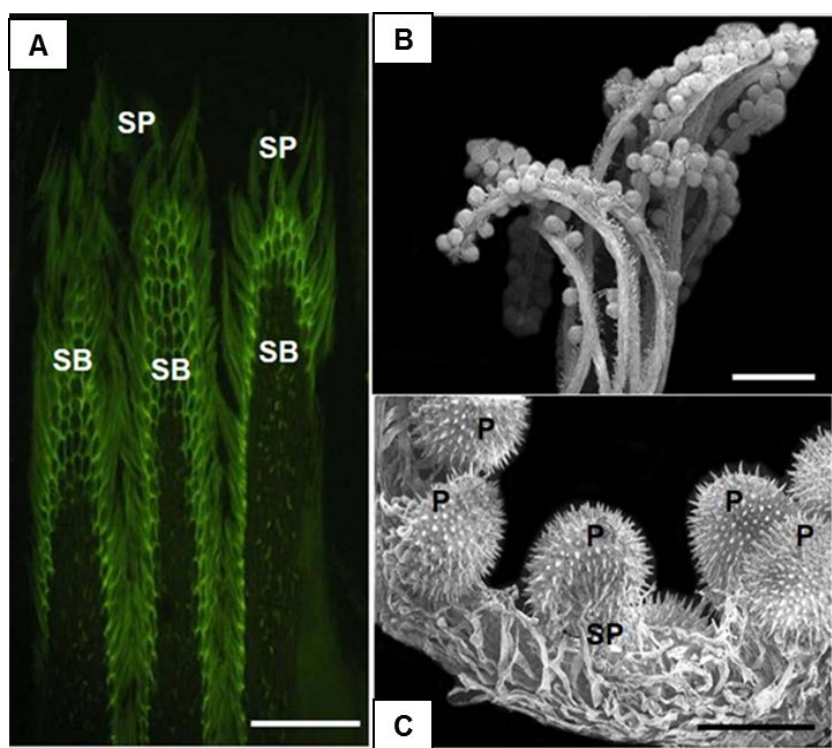

Fig. 9. Stage 12: Stigma receptivity. A. Three of the ten branched mature stigma. B. SEM analysis of ten branched stigma. C. SEM analysis of the stigmatic papillae with pollen grains. P: Pollen, SB: Stigmatic branches, SP: Stigmatic papillae. Bar: $5 \mu \mathrm{m}(\mathrm{A}), 500 \mu \mathrm{m}(\mathrm{B}), 100 \mu \mathrm{m}(\mathrm{C})$

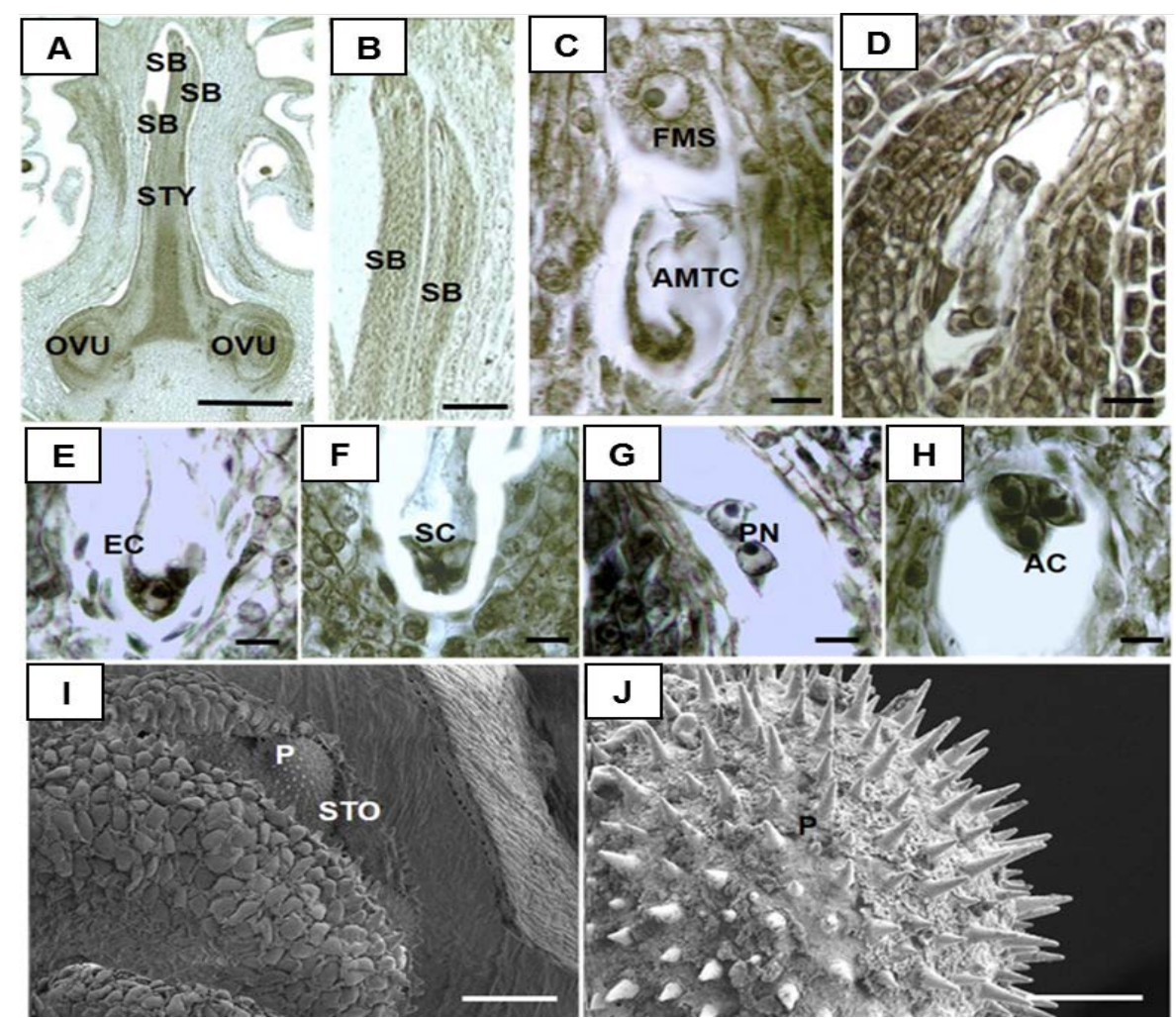

Fig. 8. Stage 11: Stigma formation. A. Ten branched stigma differantiation. B. Young stigma branches without papillae. C. Functional megaspore and atrophied megaspore cells. D. Four- nucleated embryo sac. E. Egg cell. F. Synergids. G. Polar nuclei. H. Antipodal cells. I. SEM analysis of anther dehiscence by stomium. J. SEM analysis of exine structure of mature pollen grain with short and spike like projections. AC: Antipodal cells, AMTC: Atrophied megaspore tetrad cells, EC: Egg cell, FMS: Functional megaspore, OVU: Ovule, P: Pollen, PN: Polar nuclei, SB: Stigmatic branches, SC: Synergid cells, STO: Stomium, STY: Style. Bar: $1 \mu \mathrm{m}(\mathrm{C}, \mathrm{D}, \mathrm{E}, \mathrm{F}, \mathrm{G}, \mathrm{H}), 5 \mu \mathrm{m}(\mathrm{B}), 10 \mu \mathrm{m}(\mathrm{A}), 20 \mu \mathrm{m}(\mathrm{J}), 100 \mu \mathrm{m}(\mathrm{I})$ 


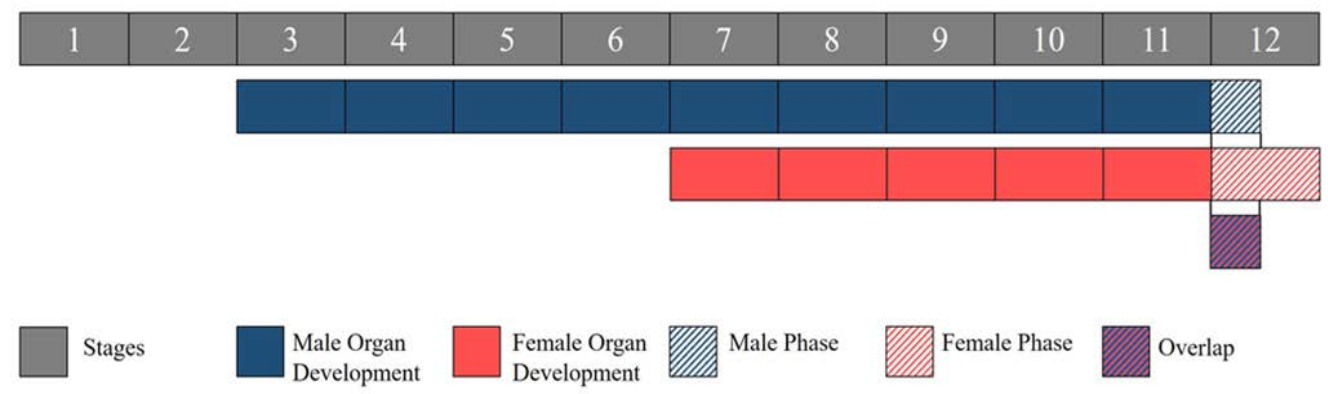

Fig. 10. Timing of reproductive organs maturity and sexual phase changes in incomplete proterandrous Malva sylvestris

The comparative description of the developmental stages in male and female sexual organs of $M$. sylvestris is given (Fig. 10). It is revealed that male organ gains maturity before the female one attains receptivity (proterandry), but reproductive activity of the male and female organs overlap for a while. Thus, this species exhibits incomplete proterandreous dichogamy.

\section{Discussion}

In the present study, the comparative development of the male and female reproductive organs in dichogamous Malva sylvestris was carried out with a consideration of maturity timing.

Hermaphrodite flowers have evolved many mechanisms and modify floral development to promote crosspollination through mechanisms such as dichogamy (Nasrallah and Nasrallah, 1993). Balthazar et al. (2004) stated that Malvoidea members generally exhibit dichogamy and $M$. sylvestris shows proterandrous dichogamy as M. moscalata (Foote, 2006).

In proterandrous species, male phase is followed by female phase, as mentioned in proterandrous Alcea rosea $\mathrm{L}$. (Malvaceae) (Li et al., 2012). Although male phase is characterized by anther maturation and pollen shedding; stigma maturation, papillate stigmatic surface and opened stigmatic branches are the characteristics of female phase (Kubitzki and Kutz, 1984; Lloyd and Webb, 1986; Çetinbaş and Ünal, 2014). As evidenced by histological analysis carried out in this study, when anthers become mature and pollen dispersal starts, stigma is not papillate and stigmatic branches are not open in $M$. sylvestris. Previous work on proterandrous $A$. rosea demonstrated the similar evidence; when anthers dehisce and pollen grains are shed, stigmatic branches are hidden (Li et al., 2012). Furthermore, Bhardwaj and Eckert (2001) adverted the sexual phases in synchronous dichogamous Butomus umbellatus. They defined the male phase by anther dehiscence, in which carpels are small and light pink, and stigmas appear undeveloped and tightly closed. Additionally female phase is described by the initiation and duration of stigma receptivity and stigma surfaces with papillae are gradually revealed as the distal edges of the ovary wall curl outward (Bhardwaj and Eckert, 2001).

Very few studies have defined dichogamy in respect to the overlap between the sexual phases under natural pollination (Jonsson et al., 1991; Wells and Lloyd, 1991;
Robertson and Lloyd, 1993; Bell and Cresswell, 1998; Griffin et al., 2000). By serial histological sections, our results clearly demonstrated that the reproductive strategy of $M$. sylvestris is incomplete proterandrous dichogamous; reproductive maturity of stamen and pistil overlap for a short time, as shallowly mentioned by Kumar et al. (2014). Similar results were achieved in proterandrous incomplete Helianthus annuus, in which presentation of male and female reproductive organs overlap for a while (Çetinbaş and Ünal, 2014).

Dichogamy is considered as a mechanism to increase cross-fertilization by limiting the pollen transfer between flowers (Darwin, 1876). Proterandry is less effective than proterogyny in preventing self-pollination. Because selffertilization may be seen in proterandry if the pollen persists and maintains viability until stigma branches open (Faegri and Pijl, 1979). Furthermore, self-pollination is substantially prevented in the presence of complete dichogamy. However, if dichogamy is incomplete, there may be different outcomes for proterandry and proterogyny, and self-pollination may occur (Faegri and Pijl, 1979; Bawa and Beach, 1981; Webb, 1981). Due to protandry avoid to self-pollination, $M$. sylvestris is a predominantly cross pollinated species (Kumar et al., 2014). On the other hand, self-fertilization may also occur in M. sylvestris due to the overlapping of maturity time of sex organs.

Dichogamy is more common in plants with large flowers compared to those with small flowers (Henslow, 1888). Large and attractive flowers tend to be protandrous (Çetinbaş and Ünal, 2014), as early reported by Wilson (1878). Proterandrous M. sylvestris have purple petals and a rather spectacular appearance, supporting this approach. Moreover, proterandry is more common in species with biotic pollination and the pollinator agents are usually birds and bees (Behrens, 1885). In proterandrous M. sylvestris, large size of bright purple petals make the flowers attractive for pollinating insects (Kumar et al., 2014).

In parallel to proterandry in $M$. sylvestris, stamen primordia differentiated before carpel primordia. Apical meristem differentiates as a roundish bulge in early stages of flower development and it consists of sequential cell layers as noted before (Grant et al., 1994). All floral organ primordia of M. sylvestris develop as a result of mitotic divisions in floral meristem cells, as in other plants (Uhl, 2011).

All Malvoideae share the following pattern of floral development: sepal, a more or less distinct 
294

corolla/androecium units and carpel formation, respectively (Balthazar et al., 2004). Balthazar et al. (2004) noted that a pentagonal corolla/androecium ring wall arises into five sectors on the floral meristem, following sepal formation in Lavatera cachmeriana (Malvoideae). Afterwards, secondary androecial primordia are initiated. Similarly, shortly after the diferantiation of stamen primordia, floral meristem cells differentiate into roundish ten carpel primordia in $M$. sylvestris. However, in the other members of Malvaceae the numbers of carpel primordia originated from floral meristem vary in number, e.g. five in Alyogyne cuneiformis and Hibiscus trionum, three or four in Gossypium hirsutum (Balthazar et al., 2004).

\section{Conclusions}

This study provides the first comparative histological description of sexual organ development in M. sylvestris, a proterandrous species, suggesting the importance of tight correlation between pollen dispersal and stigma receptivity.

\section{References}

Atsmon D, Galun E (1960). A morphogenetic study of staminate, pistillate and hermaphrodite flowers in Cucumis sativus $\mathrm{L}$. Phytomorphology 10:110-115.

Balthazar M, Alverson WS, Schönenberger J, Baum DA (2004). Comparative floral development and androecium structure in Malvoideae (Malvaceae sl). International Journal of Plant Sciences 165(4):445-473.

Bawa KS, Beach JH (1981). Evolution of sexual systems in flowering plants. Annals of the Missouri Botanical Garden 68:254274.

Behrens WJ (1885). Text-book of general botany. Edinburgh.

Bell SA, Cresswell JE (1998). The phenology of gender in homogamous flowers: temporal change in the residual sex function of flowers of oil-seed rape (Brassica napus). Functional Ecology 12:298-306.

Bernier G, Havelange A, Houssa C, Petitjean A, Lejeune P (1993). Physiological signals that induce flowering. Plant Cell 5:1147-1155.

Bhardwaj M, Eckert CG (2001). Functional analysis of synchronous dichogamy in flowering rush, Butomus umbellatus (Butomaceae). American Journal of Botany 88(12):22042213.

Çetinbaş A, Ünal M (2014). An overview of dichogamy in angiosperms. Research in Plant Biology 4(5):09-27.

Darwin C (1876). The effects of cross and selffertilisation in the vegetable kingdom. London.

Davis GL (1966). Systematic embryology of the angiosperms. John Wiley \& Sons Inc, New York

Faegri K, Pijl L (1979). The principles of pollination ecology, Oxford.

Farina A, Doldo A, Cotichini V, Rajevic M, Quaglia MG, Mulinacci N, Vincieri FF (1995). HPTLC and reflectance mode densitometry of anthocyanins in Malva silvestris L.: a comparison with gradientelution reversed-phase HPLC. Journal of pharmaceutical and biomedical analysis 14:203-211.

Foote KC (2006). Musk Mallow (Malva moschata L.). New York Flora Association Newsletter 17:1-5.
Ghorbani A (2005). Studies on pharmaceutical ethnobotany in the region of Turkman Sahra, North of Iran. Journal of Ethnopharmacology 102:58-68.

Grant S, Houben A, Vyskot B, Siroky J, Pan WH, Macas J, Saedler H (1994). Genetics of sex determination in flowering plants. Developmental Genetics 15:214230.

Griffin SR, Mavraganis K, Eckert CG (2000). Experimental analysis of protogyny in Aquilegia canadensis (Ranunculaceae). American Journal of Botany 87:1246-1256.

Henslow G (1888). The origin of floral structures through insect and other agencies. London.

Heslop-Harrison Y, Shivanna KR (1977). The receptive surface of the angiosperm stigma. Annals of Botany 41(6):1233-1258.

Hickey M, Clive K (1997). Common families of flowering plants. Cambridge University Press.

Hussain L, Ikram J, Rehman K, Tariq M, Ibrahim M, Akash MSH (2014). Hepatoprotective effects of Malva sylvestris L. against paracetamol-induced hepatotoxicity. Turkish Journal of Biology 38(3):396-402.

Jonsson O, Rosquist G, Wide'NN (1991). Operation of dichogamy and herkogamy in five taxa of Pulsatilla. Ecography 14:206-271.

Kinney MS, Columbus JT, Friar EA (2008). Unisexual flower, shoepikelet, and inflorescence development in monoecious/dioecious Bouteloua dimorpha (Poaceae, Chloridoideae). American Journal of Botany 95(2):123-132.

Kubitzki K, Kurz H (1984). Synchronized dichogamy and dioecy in neotropical Lauraceae. Plant Systematics and Evolution 147:253266.

Kumar G, Kadam GB, Saha TN, Girish KS, Tiwari AK, Kumar R (2014). Studies on floral biology of Malva sylvestris L. Indian Journal of Horticulture 71(2):295-297.

Li Q, Ruan CJ, Teixeira da Silva JA, Wang XY (2012). Floral morphology and mating system of Alcea rosea (Malvaceae). Plant Ecology and Evolution 145(2):176-184.

Lloyd DG, Webb CJ (1986). The avoidanceo f interference between the presentation of pollen and stigmas in angiosperms. 1. Dichogamy. New Zealand Journal of Botany 24:135-162.

Morbey YE, Ydenberg RC (2001). Protandrous arrival timing to breeding areas: a review. Ecology Letters 4:663-673.

Nasrallah JB, Nasrallah ME (1993). Pollen-stigma signaling in the sporophytic self-incompatibility response. Plant Cell 5:1325-1335.

Pirbalouti AG, Yousefi M, Nazari H, Karimi I, Koohpayeh A (2009). Evaluation of burn healing properties of Arnebia euchroma and Malva sylvestris. Electronic Journal of Biology 5(3):62-66.

Platt AKA, Oross JW, Thomson WWW (1983). Ultrastructural study of the development of oil cells in the mesocarp of avocado fruit. Botanical Gazzette 144(1):49-55.

Razavi SM, Zarrini G, Molavi G, Ghasemi G (2011). Bioactivity of Malva sylvestris $\mathrm{L}$, a medicinal plant from Iran. Iranian Journal of Basic Medical Sciences 14(6):574-579.

Robertson AW, Lloyd DG (1993). Rates of pollen deposition and removal in Myosotis colensoi. Functional Ecology 7:549-559.

Routley MB, Bertin RI, Husband BC (2004). Correlated evolution of 
dichogamy and self-incompatibility: a phylogenetic perspective. International Journal of Plant Sciences 165:983-993.

Stevens PF (2001 onwards). Angiosperm Phylogeny Website. Version 12. Retrieved July 2012 from http://www.mo bot.org/MOBOT/ research/APweb/.

Topçuoğlu N, Selvi N, Dokumaci E (2009). The comparison of critical point drying and drying with Hexamethyldisilazane methods for the preparation of mice tissues for scanning electron microscopy II. Lung and stomach Findings. Anadolu University Journal of Science and Technology 1:127-132.
Uhl WN (2011). Developmental studies in Ptychosperma (Palmae). II. The staminate and pistillate flowers. American Journal of Botany 63(1):97-109.

Webb CJ (1981). Andromonoecism, protandry and sexual selection in Umbelliferae. New Zealand Journal of Botany 19:335-338.

Wells MS, Lloyd DG (1991). Dichogamy, gender variation and bethedging in Pseudowintera colorata. Evolutionary Ecology 5:310-326.

Wilson AS (1878). On the association of an inconspicuous corolla with proterogynous dichogamy in insect-fertilised flowers. Nature 18:508-509. 